\title{
Revolusi Ilmiah: Global Positioning System (GPS) Sebagai Bukti Empiris Teori Relativitas
}

\author{
Sri Hartini \\ Program Studi Pendidikan IPA Universitas Pendidikan Indonesia \\ e-mail: srihartini@upi.edu
}

\begin{abstract}
Permasalahan paradoks kembar yang muncul pada abad ke-20 tidak dapat dijelaskan dengan teori ruang dan waktu Newton yang bersifat mutlak sehingga menyebabkan munculnya revolusi ilmiah dalam Fisika. Revolusi ilmiah ini telah mengubah cara pandang manusia mengenai alam semesta secara mendasar. Paradigma baru tersebut adalah paradigma tentang konsep ruang dan waktu serta konsep alam semesta yang dikemukakan oleh Einstein yaitu teori relativitas. Teori relativitas Einstein meliputi teori relativitas khusus dan teori relativitas umum. Hukum-hukum fisika yang terdapat di teori relativitas dapat ditemui di kehidupan sehari-hari. Salah satunya pada Global Positioning System (GPS). GPS adalah satu-satunya sistem satelit navigasi global untuk penentuan lokasi, kecepatan, arah, dan waktu yang telah beroperasi secara penuh di dunia saat ini. GPS merupakan bukti empiris dari teori relativitas Einstein.
\end{abstract}

Kata Kunci: revolusi ilmiah, gps, relativitas

\begin{abstract}
The problem of the twin paradox that emerged in the 20th century cannot be explained by Newton's space and time theory which is absolute, causing a scientific revolution to emerge in Physics. This scientific revolution has changed the human perspective about the universe fundamentally. The new paradigm is the paradigm of the concepts of space and time and the concept of the universe proposed by Einstein, namely the theory of relativity. The theory of Einstein's relativity includes the special theory of relativity and the general theory of relativity. The laws of physics contained in the theory of relativity can be found in everyday life. One of them is on the Global Positioning System (GPS). GPS is the only global navigation satellite system for determining the location, speed, direction and time that has been fully operational at the world today. GPS is empirical evidence from Einstein's relativity theory.
\end{abstract}

Keywords: scientific revolution, gps, relativity

\section{Pendahuluan}

Sejarah menunjukkan pengetahuan dan sains berkembang sangat pesat. Fuller (Schilling, 2013) penggagas istilah knowledge double curve menyatakan bahwa bahwa hingga awal Abad ke-20 pengetahuan umat manusia hanya bertambah sekitar dua kali lipat setiap abad. Pada akhir Perang Dunia II pengetahuan bertambah dua kali lipat setiap 25 tahun. Seiring dengan ditemukannya teknologi nano pertambahan pengetahuan menjadi dua kali lipat setiap dua tahun. Dalam waktu beberapa tahun ke depan, Internasional Business Machines (IBM) bahkan meramalkan akan terjadi ledakan pelipatgandaan pengetahuan setiap 12 jam. Dalam perkembangan pengetahuan terdapat penggantian gagasan-gagasan ilmiah lama oleh yang baru sesuai dengan fakta-fakta baru yang ditemukan, sehingga terbedakan gagasan modern dari gagasan klasik (Firman, 2018). Sejarah sains pada dasarnya merupakan sejarah pikiran umat manusia, terlepas dari asal usul kebangsaan maupun asal mula negara. Lintasan sejarah sains yang terbaik adalah mengikuti pembagian kurun waktu dari satu zaman yang terdahulu ke zaman berikutnya. Zaman tertua dari pertumbuhan sains adalah zaman kuno yang merentang antara tahun kurang lebih 4000 SM - 400 M (Muksin ,2016)

Fisika merupakan cabang dari sains. Terdapat perkembangan Fisika yang paling mencolok pada abad ke-20 yaitu relativitas oleh Albert Einstein pada 1905 dan teori kuantum oleh Max Planck pada 1900. Dua perkembangan ini adalah contoh revolusi ilmiah yang telah 
mengubah cara pandang manusia mengenai alam semesta secara mendasar. Khun menyatakan bahwa sains berkembang melalui pergeseran paradigma yaitu perubahan fundamental dalam asumsi, teori, dan metode dalam bingkai paradigma lama ke asumsi, teori, dan metode dalam bingkai paradigma baru (Firman, 2018). Pergeseran paradigma adalah istilah yang cocok untuk menggambarkan terjadinya dimensi kreatif pikiran manusia dalam bingkai pengetahuan (Saputra, 2018).

Gagasan baru dalam revolusi ilmiah teori relativitas Einstein meliputi teori relativitas khusus dan teori relativitas umum. Hukum-hukum fisika yang terdapat pada teori relativitas dapat ditemui di kehidupan sehari-hari. Salah satunya adalah Global Positioning System (GPS). GPS adalah satu-satunya sistem satelit navigasi global untuk penentuan lokasi, kecepatan, arah, dan waktu yang telah beroperasi secara penuh di dunia saat ini. GPS merupakan bukti empiris dari teori relativitas sebagai bagian dari revolusi ilmiah GPS adalah singkatan dari Global Positioning System, yang merupakan sistem navigasi dengan menggunakan teknologi satelit yang dapat menerima sinyal dari satelit (Sandro,2017).

Perkembangan teknologi informasi telah berkembang, salah satunya pada pembuatan aplikasi yang sudah dapat dikembangkan pada perangkat smartphone berbasis android yang dapat dengan mudah digunakan serta dapat menyediakan informasi secara cepat dan efisien. Salah satu fitur yang terdapat dalam smartphone adalah layanan internet dan dilengkapi dengan fitur GPS (Global Positioning System), yaitu sistem navigasi yang menggunakan sinyal satelit dalam penggunaannya. Dengan adanya GPS pengguna smartphone dapat mengetahui koordinat dari pengguna, yaitu berupa data latitude dan longitude. GPS dapat menghitung informasi, seperti kecepatan, arah yang dituju, jalur, tujuan perjalanan, jarak tujuan, matahari terbit dan matahari terbenam dan lainlain. Sinyal yang dikirimkan oleh satelit ke GPS akan digunakan untuk menghitung waktu perjalanan (travel time). Penerapan lokasi dengan LocationBased Services (LBS) atau layanan berbasis lokasi yang mampu mendeteksi letak pengguna juga dapat memberikan layanan informasi yang dibutuhkan sesuai dengan letak pengguna tersebut. LBS ini juga memanfatkan fungsi teknologi GPS dan cell-besed location dari Google. Dalam mengukur posisi, LBS menggunakan lintang dan bujur untuk menentukan lokasi geografis ( Eka ,2017).

\section{Metode}

Jenis penelitian ini adalah studi literatur dengan mencari referensi teori yang relevan dengan kasus yang diangkat pada artikel ini. Kasus yang dibahas pada artikel ini adalah revolusi ilmiah: GPS sebagai bukti empiris teori relativitas .

\section{Hasil dan Pembahasan}

\section{Teori Relativitas}

Teori relativitas merupakan hasil pemikiran Albert Einstein yang merevisi pandangan fisika terhadap teori gravitasi. Teori relativitas merupakan hukum fisika yang sejauh ini bersifat universal. Melalui teori relativitas, cahaya dan gravitasi di bumi menjadi dapat dipahami dan dapat diperkirakan seperti apa keduanya berperilaku di hampir seluruh ruang alam semesta. Teori relativitas berhasil mengubah landasan teori dari fisika dan astronomi sepanjang abad ke20 (Hidayat, 2010). Teori relativitas mampu mengakhiri era 200 tahun teori mekanika yang pertama kali dikemukakan oleh Newton.

Teori relativitas dari Einstein dibagi menjadi relativitas khusus dan umum. Relativitas khusus muncul pertama kali dan membahas tentang kecepatan cahaya yang bersifat konstan bagi setiap orang. Teori ini terlihat sederhana, namun ternyata menimbulkan konsekuensi yang mendalam. Einstein menyimpulkan teori ini pada 1905 setelah munculnya bukti eksperimental yang menunjukkan bahwa kecepatan cahaya tidak berubah saat bumi mengitari matahari. Hasil ini cukup mengejutkan dunia fisika karena masih menganggap kecepatan bagi hampir seluruh objek bergantung pada arah yang diamati pengamat. Jika seseorang mengendarai mobil di sebelah jalur kereta api, seseorang akan menyadari bahwa kereta akan bergerak jauh lebih cepat jika mobil bergerak berlawanan dibanding jika mobil bergerak searah dengan kereta api. Menurut Einstein, setiap pengamat akan mengukur kecepatan cahaya pada $299.792 .458 \mathrm{~m} / \mathrm{s}$ terlepas dari seberapa cepat pengamat bergerak atau kemana arah gerak pengamat (Anugraha, 2018). Namun muncul berbagai pertanyaan, seperti bagaimana jika seseorang berada pada pesawat luar angkasa yang bergerak pada kecepatan cahaya, dan menyalakan lampu. 
Beberapa ahli fisika menjawab bahwa lampu akan tetap menyala seperti biasa, tapi hanya dari sudut pandang seseorang yang berada di dalam pesawat. Jika seseorang di luar mengamati bagaimana pesawat tersebut bergerak, lampu tersebut tidak akan menyala. Butuh waktu yang sangat lama sampai lampu tersebut tampak menyala bagi orang yang berada diluar pesawat. Namun jawaban ini menimbulkan kontroversi. Jika kecepatan cahaya dianggap konstan seperti yang disampaikan Einstein, berarti ruang dan waktu tidak bersifat mutlak. Keduanya mesti bersifat relatif.

Pada kasus lainnya, terdapat pesawat luar angkasa raksasa dengan kecepatan 99,99\% kecepatan cahaya. Pesawat akan hanya terlihat kecil sekali bagi pengamat di luar pesawat, sementara pesawat akan tetap terlihat sesuai ukuran normal bagi orang yang berada di dalam pesawat. Selain itu, teori relativitas dapat membuat waktu melambat saat suatu objek bergerak semakin cepat. Jika sepasang kembar dipisahkan, dimana salah seorang menjelajah menggunakan pesawat luar angkasa dan kemudian kembali lagi ke bumi, seseorang akan menjadi lebih muda dibanding saudaranya yang tetap di bumi.

Selain ruang dan waktu, massa juga akan berubah. Semakin cepat suatu objek bergerak, semakin berat massa suatu objek. Faktanya, tidak ada objek pesawat luar angkasa yang dapat mencapai $100 \%$ dari kecepatan cahaya. Jika hal ini terjadi, maka massa pesawat tersebut akan melonjak menjadi menuju tak hingga. Hubungan antara massa dan kecepatan seringkali ditampilkan dalam persamaan $\mathrm{E}=\mathrm{mc}^{2}$, dimana $E$ merupakan energi, $m$ adalah massa, dan $c$ adalah kecepatan cahaya.

Einstein belum sepenuhnya memahami hubungan antara ruang dan waktu pada saat mengemukakan teori relativitas khusus. Einstein berusaha menggeneralisasi teorinya dengan melibatkan percepatan dan menemukan bahwa fenomena tersebut dapat mengganggu bentuk dari ruang dan waktu. Einstein berusaha mengembangkan persamaan matematika kompleks untuk menjawab masalah ini dan memerlukan waktu sekitar sepuluh tahun untuk menyelesaikannya. Einstein menemukan bahwa ruang dan waktu akan melengkung pada sebuah objek raksasa, dan lengkungan tersebut merupakan sesuatu yaitu gaya gravitasi. Sulit untuk menggambarkan bagaimana geometri lengkungan dari relativitas umum, tapi dapat dibayangkan sebagai sebuah kain yang terbentang dengan beberapa benda ringan. Jika terdapat benda berat yang diletakkan pada kain tersebut, maka kain akan menjadi melengkung dan membuat objek yang berada disekitarnya tidak lagi bergerak pada lintasan lurus.

Persamaan relativitas umum ini berhasil memprediksi sejumlah fenomena, dimana beberapa diantaranya telah terbukti, seperti: pembengkokan cahaya pada sebuah objek raksasa, evolusi dari orbit planet Merkurius, percepatan periode rotasi dari bintang biner dan pulsar, gelombang gravitasi yang disebabkan ledakan kosmik dan keberadaan lubang hitam yang dapat menarik segala sesuatu tanpa bisa keluar, termasuk cahaya serta pembengkokan ruang-waktu disekitar lubang hitam yang jauh lebih besar dibanding lokasi manapun (Anugraha, 2018).

Menurut Einstein, kedua teori relativitas ini merupakan sebuah teori dasar. Teori ini dikembangkan melalui metode analitis. Hal ini menunjukkan bahwa setiap elemen yang bekerja menurut teori ini bukanlah sesuatu yang bersifat hipotesis, melainkan berdasarkan temuan empiris. Model matematis yang dikembangkan adalah sesuatu yang terpisah dengan proses natural yang terjadi. Oleh karena itu, terdapat persyaratan kondisional yang mesti dipenuhi agar teori ini dapat disimpulkan.

\section{GPS}

Global Positioning System (GPS) merupakan sebuah alat atau sistem yang dapat digunakan untuk mengetahui posisi seseorang (secara global) dipermukaan bumi berbasis satelit. Data dikirim dari satelit berupa sinyal radio dengan data digital. Sistem ini pertama kali digunakan oleh Departemen Pertahanan Amerika Serikat tahun 1978 dan pada tahun 1994 sudah memakai 24 satelit. GPS adalah satu-satunya sistem satelit navigasi global untuk penentuan lokasi, kecepatan, arah, dan waktu yang telah beroprasi secara penuh didunia saat ini (Abidin, dkk: 2011).

GPS mempunyai tiga komponen utama, yaitu: satelit, pengendali, dan penerima/pengguna. Satelit berfungsi untuk menerima dan menyimpan data yang ditranmisikan oleh stasiun-stasiun pengontrol. Menyimpan dan menjaga informasi waktu berketelitian tinggi (ditentukan dengan jam atomik di satelit), dan memancarkan sinyal dan informasi secara kontinu ke pesawat penerima (receiver) dari pengguna. Pengontrol berfungsi untuk mengendalikan dan mengontrol satelit dari bumi baik untuk mengecek kesehatan satelit, penentuan dan prediksi orbit waktu, sinkronisasi waktu antar satelit, dan mengirim data ke 
satelit. Penerima berfungsi menerima data dari satelit dan memprosesnya untuk menentukan posisi (posisi tiga dimensi yaitu koordinat di bumi plus ketinggian), arah, jarak dan waktu yang diperlukan oleh pengguna. Ada dua macam penerima yaitu tipe navigasi dan geodetic (Bangun, 2008).

GPS menggunakan 24 satelit yang mengorbit bumi dengan jarak sekitar $12.000 \mathrm{~km}$ di atas bumi. Satelit ini bergerak dengan kecepatan sekitar $7.000 \mathrm{~km} / \mathrm{jam}$ dengan menggunakan tenaga surya. Satelit ini juga memiliki baterai yang dipasang secara onboard untuk mengantisipasi saat terjadi gerhana matahari, atau ketika tidak mendapat cahaya matahari, serta dilengkapi dengan roket pendorong untuk menjaga satelit tetap berada pada orbitnya. Setiap daerah di atas permukaan bumi ini minimal terjangkau oleh tiga sampai empat satelit. GPS terbaru bisa menerima sampai dengan 12 chanel satelit sekaligus. Kondisi langit yang cerah dan bebas dari halangan membuat GPS dapat dengan mudah menangkap sinyal yang dikirimkan oleh satelit. Semakin banyak satelit yang diterima oleh GPS, maka akurasi yang diberikan juga akan semakin tinggi.

Cara kerja GPS secara sederhana ada lima langkah, yaitu : (1) Memakai perhitungan triangulation dari satelit; (2) GPS mengukur jarak menggunakan waktu tempuh sinyal radio melalui perhitungan triangulation; (3). GPS memerlukan memerlukan akurasi waktu yang tinggi dalam mengukur waktu tempuh; (4). Mengetahui dengan pasti posisi satelit dan ketingian pada orbitnya untuk menghitung jarak dan (5) Menggoreksi sinyal tunda pada waktu perjalanan di atmosfer sampai diterima penerima (Bangun: 2008). Satelit GPS dalam mengirim informasi waktu sangat presisi sehingga dapat menentukan informasi lokasi pengguna dengan akurat.

\section{Revolusi ilmiah: GPS sebagai bukti empiris teori Relativitas}

Manusia adalah makhluk yang diciptakan oleh Tuhan dengan keingintahuan yang sangat besar. Hal ini yang mendorong untuk menemukan pengetahuan yang kemudian dikenal dengan istilah berfilsafat. Namun seiring perkembangan pengetahuan, filosofi dianggap sudah tidak mengimbangi kemajuan terkini dalam sains, terutama fisika. Para ilmuwan telah menjadi pelopor penemuan dalam perjalanan pencarian pengetahuan.

Revolusi sains diawali dengan munculnya berbagai penemuan oleh ilmuwan. Salah satu dampak utama dari revolusi sains adalah perubahan pandangan dunia yang menaungi para ilmuwan dalam seluruh aktivitas ilmiah (Kuhn: 1989). Paradigma menjadi patokan bagi ilmu pengetahuan untuk melakukan penelitian, memecahkan masalah bahkan menyeleksi masalah apa saja yang layak diperbincangkan.

Perubahan paradigma menyebabkan para ilmuwan melihat dunia secara berbeda. Paradigma ilmu pengetahuan menurut Kuhn (1989) adalah ilmu pengetahuan adalah hasil kesepakatan intersubjektif. IImu pengetahuan berkembang secara revolusioner. Selanjutnya perkembangan ilmu pengetahuan melalui subjek peneliti dalam satu komunitas. Menurut Kuhn (1989), rumus perkembangan ilmu pengetahuan adalah Paradigma 1-IImu Pengetahuan Normal-Anomali-Krisis-Paradigma 2.

Munculnya revolusi sains karena adanya anomali-anomali yang semakin parah dan adanya krisis yang tidak dapat terpecahkan oleh paradigma yang dijadikan referensi penelitian. Terjadinya revolusi sains bukan hal yang mulus tanpa hambatan. Revolusi sains merupakan suatu keadaan perkembangan non-kumulatif dimana didalamnya terdapat pergantian sebagian atau keseluruhan paradigma lama dengan paradigma baru yang telah dimunculkan. IImu pengetahuan baru harus menggantikan ketidaktahuan, bukan menggantikan jenis pengetahuan yang telah ada sebelumnya.

Salah satu revolusi ilmiah dalam fisika adalah perkembangan mekanika klasik Newton berkembang menjadi mekanika relativistik oleh Einstein. Teori klasik Newton mengenai ruang dan waktu menyisakan keganjalan-keganjalan yang mengusik rasa keingintahuan para ilmuwan untuk terus mengembangkan ilmu pengetahuan. Memasuki abad ke-19, sebuah peristiwa yang termahsyur yakni peristiwa dua orang kembar yang terpisah (paradoks kembar). Seseorang yang ada di bumi setelah berpuluh tahun lamanya mendapati saudara kembarnya yang telah melakukan perjalanan dari luar angkasa memiliki perbedaan umur dengan dirinya. Saudara kembarnya berumur lebih muda dari pada dirinya. Kasus seperti ini tidak dapat dijawab dengan menggunakan teori ruang dan waktu oleh Newton yang menyatakan bahwa waktu adalah mutlak dimanapun tempatnya. Oleh karena itu, diperlukan suatu gagasan baru mengenai konsep ruang dan waktu serta pandangan baru mengenai konsep alam semesta.

Gagasan baru tersebut yakni teori relativitas Einstein meliputi teori relativitas khusus dan teori relativitas umum. Kedua teori inilah yang memberikan pandangann baru mengenai konsep ruang-waktu empat dimensi serta bentuk alam semesta yang berhingga tapi tak 
terbatas. Secara umum, teori ini berbicara tentang tiga hukum fisika dasar. Pertama, tidak ada hal mutlak yang dapat dijadikan referensi atau kerangka acuan dalam menentukan sesuatu. Termasuk saat mengukur kecepatan, momentum, dan perjalanan waktu yang dialami sebuah benda. Selalu ada hal yang mempengaruhi kondisi-kondisi tersebut. Kedua, kecepatan cahaya selalu sama, terlepas dari siapa atau seberapa cepat orang tersebut mengukurnya. Ketiga, tidak ada yang lebih cepat dari kecepatan cahaya.

Dalam penerapannya, teori relativitas banyak digunakan pada perangkat elektronik modern seperti GPS. GPS banyak digunakan pada bidang militer, mengetahui jalur navigasi secara akurat pada mobil dan pesawat, sistem informasi geografis, dan pemantauan gempa bumi.

Satelit sebagai pusat informasi GPS menggunakan relativitas sebagai dasar teorinya. Meskipun satelit tidak bisa mengikuti kecepatan cahaya, namun satelit sangat cepat dalam teknologi yang diciptakan manusia untuk memberikan sinyal ke stasiun di bumi. Berdasarkan teori relativitas, pergerakan detik di Bumi lebih lambat daripada di satelit karena pengaruh gravitasi. Teori ini juga mengatakan bahwa jam yang sedang bergerak (misalnya jam di satelit atau di mobil yang berjalan) ternyata lebih lambat daripada jam yang dalam posisi diam. Hal ini menyebabkan terjadinya dilatasi waktu relativistik pada jam sekitar empat mikrodetik setiap harinya. Ditambah dengan efek gravitasi menjadi sekitar tujuh mikrodetik atau 7000 nanodetik. Jumlah kecil ini bisa memberi perbedaan besar dalam mekanismne GPS sampai beberapa kilometer (Fisika Indonesia: 2015). Peranan teori relativitas sangat besar sekali dalam teknologi GPS untuk meningkatkan keakuratan pengukuran posisi objek di permukaan bumi. Tanpa peranan teori relativitas khusus dan umum kemungkinan besar teknologi GPS tidak dapat digunakan.

\section{Kesimpulan}

Permasalahan paradoks kembar yang muncul pada abad ke-20 tidak dapat dijelaskan dengan teori ruang dan waktu oleh Newton yang bersifat mutlak sehingga menyebabkan munculnya revolusi ilmiah. Revolusi ilmiah ini telah mengubah cara pandang manusia mengenai alam semesta secara mendasar. Paradigma baru tersebut adalah teori relativitas Einstein meliputi teori relativitas khusus dan teori relativitas umum. Hukum-hukum fisika yang terdapat di teori relativitas dapat ditemui di kehidupan sehari-hari. Salah satunya adalah GPS yang saat ini banyak digunakan pada bidang militer, mengetahui jalur navigasi secara akurat pada mobil dan pesawat, sistem informasi geografis, dan pemantauan gempa bumi. Peranan teori relativitas sangat besar sekali dalam teknologi GPS untuk meningkatkan keakuratan pengukuran posisi objek di permukaan bumi. Tanpa peranan teori relativitas khusus dan umum kemungkinan besar teknologi GPS tidak dapat digunakan.

\section{Daftar Pustaka}

Abidin, H.Z., Jones, A., dan Kahar, J. (2011). Survei dengan GPS. Bandung: Penerbit ITB

Anugraha, R.N.Q.Z. (2018). Pengantar Teori Relativitas dan Kosmologi. Yoyakarta: UGM Press

Bangun, M.Br. (2008). Pemanfaatan dan Aplikasi Teknologi Sistem Satelit GPS dalam Penentuan Posisi Geografis Pengguna. Jakarta: LAPAN

Eka ,R. (2106) Implementasi Global Positioning System (GPS) dan Location Based Service (LSB) pada Sistem Informasi Kereta Api untuk Wilayah Jabodetabek. Jurnal Sisfotek Global

Firman, H. (2018). Pengantar Filsafat Ilmu Pengetahuan Alam Sekolah Pascasarjana UPI. Tidak diterbitkan.

Fisika Indonesia. (2015). Bukti Teori Relativitas Einstein dalam Kehidupan, https://fisika.id/2015. (diunduh tanggal 27 Maret 2019).

Hidayat, T. (2010). Teori Relativitas Einstein: Sebuah Pengantar. Bandung: Penerbit ITB

Kuhn, T.S. (1989). Peran Paradigma Dalam Revolusi Sains. Bandung : Remaja Rosdakarya. 
Muksin ,Mochamad (2016) Islam Dan Perkembangan Sains \& Teknologi. Universitas Merdeka Malang

Pradjonggo Abidin, H.Z., Jones, A., dan Kahar, J. (2011). Survei dengan GPS. Bandung: Penerbit ITB

Saputra, O. (2018). Revolusi dalam Perkembangan Astronomi: Hilangnya Pluto Dalam Keanggotaan Planet Pada Sistem Tata Surya. Jurnal Filsafat Indonesia. 1(1):71-74

Schilling. (2013). Knowledge Doubling Every 12 Months, Soon to be Every 12 Hours, http://www.industrytap.com/knowledge-doubling-every-12-months-soon-to-be-every-12hours/3950, (diunduh 27 Maret 2019). 